\title{
Research on countermeasures and suggestions of Intangible Cultural Heritage Inheritance "entering campus"
}

\author{
Yanbing Yin, Chen Liu* \\ School of Economics and Management TianGong University, Tianjin 300384, China.
}

Abstract: Aiming at the problems that the current education practice of intangible cultural heritage is not fully implemented, and the campus curriculum system of intangible cultural heritage is not perfect, this paper puts forward some relevant policy suggestions, such as the construction of intangible cultural heritage education inheritance system, modular curriculum design, building resource collaboration platform and so on. It strengthens the important role of campus in the inheritance and protection of intangible cultural heritage, and provides a good scientific development system for the inheritance and protection of intangible cultural heritage in the campus channel

Keywords: intangible cultural heritage; educational inheritance; resource collaboration platform

As the essence of Chinese traditional culture, intangible cultural heritage (referred to as intangible cultural heritage) is not only the inheritance of skills, but also the continuation of its cultural connotation. Its inheritance and development is of great significance to the in-depth excavation of Chinese excellent traditional culture and the cultivation of national self-confidence. Promoting the intangible cultural heritage into the campus not only provides a new idea for the protection and inheritance of intangible cultural heritage, but also provides a beneficial attempt to improve the cultural and artistic cultivation of teachers and students and build a high-level quality education platform.

At present, the practice of intangible cultural heritage education in China is still in the exploratory stage, and there is a lack of mature curriculum system and promotion mode. Therefore, it is necessary to construct the curriculum system of intangible cultural heritage education inheritance and explore the education mode of intangible cultural heritage into campus on the basis of exploring the advantages of intangible cultural heritage education inheritance resources. It is urgent to strengthen policy support and focus

Copyright (C) 2020 Yanbing Yin et al.

doi: $10.18282 / 1-$ e.v9i4.1687

This is an open-access article distributed under the terms of the Creative Commons Attribution Non-Commercial License (http://creativecommons.org/licenses/by-nc/4.0/), which permits unrestricted non-commercial use, distribution, and reproduction in any medium, provided the original work is properly cited.

\begin{tabular}{|l|l|}
\hline Increase capital investment & $\begin{array}{l}\text { Green technology can solve many problems such as low resource utilization, } \\
\text { serious environmental pollution, and high corporate scrap rate. If green } \\
\text { technology can be used, the problems of human resource shortage and energy } \\
\text { shortage can be solved, and environmental pollution can be prevented and } \\
\text { controlle }\end{array}$ \\
\hline $\begin{array}{l}\text { Strengthen and improve policy support for } \\
\text { green development }\end{array}$ & $\begin{array}{l}\text { Corresponding taxation and fiscal policies should be improved, and green } \\
\text { product enterprises should be given certain green preferences and enjoy tax } \\
\text { benefits. At present, my country should establish a sound energy taxation } \\
\text { mechanism and strengthen control over the use of non-renewable resources } \\
\text { such as fossil fuels. }\end{array}$ \\
\hline
\end{tabular}

\section{Conclusion}

Building green development and improving the system of ecological civilization are complementary. Green development is both a prerequisite for achieving ecological civilization and a sufficient condition for achieving ecological civilization. In summary, we have discovered the dilemmas faced by green development in today's social environment, and further analyzed, put forward the countermeasures and methods for implementing green development under the premise of ensuring ecological civilization. On the one hand, we should strengthen the publicity of green development and increase the public's or enterprises' awareness of it; on the other hand, the government needs to expand capital investment and implement multiple channels to promote the construction of ecological civilization and strengthen citizens' green awareness.

\section{References}

[1]Morrison R S. Building an Ecological Civilization[R]. Manchester:Social Anarchism: A Journal of Theory\&Practice, 2007. [2]Shimada K, Tanaka Y, Gomi K, et al. Developing a long-term local society design methodology towards a low-carbon economy: Anapplication to Shiga Prefecture in Japan [J]. Energy Policy, 2007,35(9): 4688-4703. 
on building a scientific system of intangible cultural heritage education inheritance and protection.

\section{Constructing the educational inheritance system of "four penetrations and four integrations"}

In the process of promoting the intangible cultural heritage into the campus, we can explore the construction of a threedimensional intangible cultural heritage education inheritance system of "four penetrations and four integrations".

"Four penetrations" means that intangible cultural heritage education runs through the whole stage of universities, primary and secondary schools; runs through the whole process of teaching and practice after class, inside and outside school, teaching and practice; runs through the full dimension of online and offline teaching; runs through all aspects of personnel training, cultural heritage, scientific research and social services.

"Four integrations" are the integration of intangible cultural heritage education inheritance and highlighting the regional characteristics of culture; the integration of intangible cultural heritage education and cultural heritage; the integration of intangible cultural heritage education and ideological and political education; the integration of intangible cultural heritage education inheritance and innovation and development.

\section{Developing modular curriculum system of "double classroom and multi ability"}

We should carefully excavate the cultural essence and core contents of intangible heritage, and build a modular system of "double classroom and multi ability" in the first class + second classroom with clear and scientific system.

The first class: school based module courses such as intangible cultural heritage story and intangible cultural heritage project experience are offered for students at different stages of primary and secondary schools; general module courses such as intangible cultural heritage folk culture, Convention for the protection of intangible cultural heritage, intangible cultural heritage and national culture; and professional modules such as composition principle and pattern design, new product development and brand planning Meanwhile, we should innovate teaching methods, build Internet teaching resources and realize online and offline courses based on Internet plus technology, so that students can explore the charm and essence of intangible heritage from a multidisciplinary perspective.

The second classroom: Based on the practice module, the "430 classroom" after class trusteeship, summer camp, special practice, discipline competition, exclusive interview with inheritors, field survey, innovation and entrepreneurship plan projects are carried out for students at different stages.

With the "double classroom" multi module curriculum as the carrier, we will carry out "one school with one feature, one school with one intangible cultural heritage", so as to realize the comprehensive popularization of intangible cultural heritage education, the serialization of courses, and the systematization of management, so as to cultivate students' communication and promotion ability, skills inheritance ability, cultural research ability and product innovation ability, and enhance students' cultural self-confidence and social responsibility.

\section{Cultivating a cross-border integrated teaching staff of "teachers + inheritors"}

We should set up a team of "teachers + inheritors of intangible cultural heritage" from different fields and disciplines, cooperate to develop curriculum, teaching materials, cases and other resources, establish intangible cultural heritage art associations, master studios, intangible cultural heritage practice workshops and intangible cultural heritage practice bases, and cultivate craftsman quality by hand, so as to realize the organic combination of teachers' knowledge teaching and inheritor's skill teaching, and full classroom teaching and practical operation The integration of traditional skills and modern innovation will form a "three in" teaching mode of "intangible cultural heritage into the campus, skills into the major and masters into the classroom", and build a platform for cultivating craftsman quality.

\section{Building a resource collaboration platform of "multi subject and three integration"}

Relying on the advantages of resources, the government (Intangible Cultural Heritage Center), schools and enterprises (inheritors) should be gathered to create a collaborative platform of intangible cultural heritage resources, which is "three integration" of teaching communication, experience communication and exhibition communication.

First, teaching communication platform. Combined with the modular curriculum system of "double classroom and multi ability", each collaborative subject can improve the skills and cultivation of intangible cultural heritage inheritors through the establishment of intangible cultural heritage summer camp, intangible cultural heritage cloud media, Intangible Cultural Heritage Research Institute, intangible cultural heritage micro Museum, etc.

Second, experience communication platform. We can rely on the theme activities and experience activities such as master studio, student association, student maker studio, practice workshop, practice base, maker analysis exchange meeting, intangible cultural heritage international exchange experience class and other theme activities and experience activities, so as to let students have close contact with intangible cultural heritage, experience the spiritual quality behind non heritage skills, and enhance students' sense of identity and pride of Chinese excellent traditional culture.

Third, display and communication platform. Through the school open day, graduation project open exhibition week, Beijing Tianjin Hebei joint exhibition of intangible cultural heritage, Intangible Cultural Heritage Expo, intangible cultural heritage innovation and entrepreneurship work competition and other exchange and exhibition activities, the school tells the intangible cultural heritage stories, displays the Chinese excellent traditional cultural charm, and spreads the cultural values, ideological wisdom and practical experience of the Chinese nation.

Establishing the normal working mechanism of Intangible Cultural Heritage Inheritance "entering the campus"

Do a good job in planning and design 


\title{
Research on the New Model of Education Precision Funding under the Model of Precision Poverty Alleviation
}

\author{
Haixia Yang * \\ Chongqing Normal University, Chongqing 40047, China.
}

\begin{abstract}
In recent years, the precision funding of college students with financial difficulties has been increasing. Doing a good job of "precision funding" for impoverished college students has become an important task of "funding poverty alleviation" in colleges and universities. This article elaborates on the problems of current poverty-stricken college students' financial aid work under the concept of targeted poverty alleviation and college students' precise financial aid, and analyzes the practice path of "accurate financial aid" for impoverished college students.

Keywords: Targeted poverty alleviation; Education; Targeted funding
\end{abstract}

\section{Overview of targeted poverty alleviation}

"Precision poverty alleviation" was put forward by General Secretary during his inspection in Xiangxi in 2013. He pointed out: "Poverty alleviation must be realistic and appropriate to local conditions. Targeted poverty alleviation." This idea was also issued in 2015 by the State Council The "Decision" is further explained, "Insist on targeted poverty alleviation, improve the effectiveness of poverty alleviation, and achieve true poverty alleviation, true poverty alleviation, and true poverty alleviation ${ }^{[1]}$." The idea of

Copyright (C) 2020 Haixia Yang

doi: $10.18282 / 1-$ e.v9i4.1688

This is an open-access article distributed under the terms of the Creative Commons Attribution Non-Commercial License (http://creativecommons.org/licenses/by-nc/4.0/), which permits unrestricted non-commercial use, distribution, and reproduction in any medium, provided the original work is properly cited.

The government issued normative documents to promote the establishment of the normal mechanism of intangible cultural heritage "entering the campus", clarifying the guiding ideology, work content, implementation methods, working mechanism and division of responsibilities, integrating cultural, educational and social resources, and carrying out overall planning and overall coordination from the system and mechanism.

Establish evaluation mechanism

Chinese traditional culture is broad and profound. There are many kinds of items and rich contents. We should establish a review mechanism, organize experts and scholars from many disciplines such as social sciences, culture and education to set up a variety of professional review committees, sort out and review the intangible assets into the campus resources, identify the real resources before entering the campus, extract the essence, and remove the dross, so as to ensure the healthy and excellent cultural content of the campus. Show and apply.

Improve the security mechanism

It is suggested to set up an organization and coordination organization led by the education and culture departments and participated by relevant departments to jointly promote the implementation of Intangible Cultural Heritage Inheritance "into campus", and provide necessary financial support. Make full use of cultural venues, intangible cultural heritage heritage base, red tourism base, historical and cultural cities and towns and other cultural places to establish intangible cultural heritage campus practice base and carry out students' learning and experience activities. The evaluation mechanism should be established to evaluate the performance of the activities of cultural and educational departments at all levels to promote the inheritance of intangible cultural heritage.

\section{Reference}

[1]ZHANG Zhaolin. Intangible cultural heritage theme IP: the symbiotic relationship between inheritance, activation and current young audience groups[J]. Art Research,2020(06):122-125.

[2]ZHU Run, FENG Xiaojuan. Construction and exploration of inheritance practice base of intangible cultural heritage in Colleges and Universities[J]. Laboratory Research and Exploration, 2019,38(11):270-273.

[3]JING Qiao, GAI Haihong, WANG Jingmin. Feasibility study on the integration of Hebei intangible cultural heritage and university curriculum[J]. Journal of Hebei Normal University (EDUCATION SCIENCE EDITION), 2010,12(03):126-128.

[4]LI Yang. Research on innovation mode of intangible cultural heritage tourism resources based on digital platform[J]. Packaging Engineering, 2015,36(10):32-35.

[5]YUAN Li, GU Jun. Intangible cultural heritage[M]. Beijing: Higher Education Press,2009 